\title{
Three New Resin Glycosides and a New Tetrahydropyran Derivative from the Seeds of Quamoclit pennata
}

\author{
Masateru Ono, ${ }^{*}, a$ Yoshinari Takaki, ${ }^{a}$ Masamitsu Takatsuji, ${ }^{a}$ Kousuke Akiyama, ${ }^{a}$ \\ Masafumi Okawa, ${ }^{b}$ Junei Kinjo, ${ }^{b}$ Hiroyuki Miyashita, ${ }^{c}$ Hitoshi Yoshimitsu, ${ }^{c}$ and \\ Toshihiro Nohara ${ }^{c}$ \\ ${ }^{a}$ School of Agriculture, Tokai University; 5435 Minamiaso, Aso, Kumamoto 869-1404, Japan: ${ }^{b}$ Faculty of \\ Pharmaceutical Sciences, Fukuoka University; 8-19-1 Nanakuma, Jonan-ku, Fukuoka 814-0180, Japan: and \\ ${ }^{c}$ Faculty of Pharmaceutical Sciences, Sojo University; 4-22-2 Ikeda, Kumamotonishi-ku, Kumamoto 860-0082, \\ Japan. Received April 12, 2012; accepted May 10, 2012
}

Three new resin glycosides, quamoclins V (1), VI (2), and VII (3) and a new tetrahydropyran derivative, quamopyran (4), were isolated from the seeds of Quamoclit pennata BoJER (Convolvulaceae). The chemical structures of these compounds were determined primarily on the basis of spectroscopic data. The carboxyl group of the aglycone, $11 S$-convolvulinolic acid, of 1 and 2 was linked intermoleculary with a hydroxy group of the sugar moiety to form a macrocyclic ester structure, as in already known jalapins, and 3 was an acylated glycosidic acid methyl ester. All of the sugar moieties of 1-3 were acylated by one $2 S$-methylbutyric acid. Compound 4 was a diketone having a tetrahydropyran ring.

Key words Quamoclit pennata; resin glycoside; jalapin; tetrahydropyran derivative; Convolvulaceae

Some laxative crude drugs such as Pharbitis Semen, Mexican Scammony Root, Orizaba Root, Jalapae Tuber, and Rhizoma Jalapae Braziliensis originate from Convolvulaceous plants. Their active ingredients, so-called resin glycosides, were classified by Mayer in 1855, according to their solubility in ether, into two groups, jalapin (soluble) and convolvulin (insoluble). ${ }^{1)}$ This classification has since been conventionally used. In 1993, one of the present authors proposed that the terms, "jalapin" and "convolvulin," should be used not on the basis of solubility in ether, but rather to describe structural groups, namely, resin glycosides with intramolecular cyclic ester structures, and those without, respectively. ${ }^{2,3)}$

Quamoclit pennata BOJER is a Convolvulaceae plant native to tropical regions of South America and is cultivated primarily as an ornamental plant. In a previous paper, we reported the isolation and structural elucidation of a glycosidic acid called quamoclinic acid A, $11 S$-convolvulinolic acid 11- $O-\beta$ D-glucopyranosyl-( $1 \rightarrow 3)-O$-[ $\alpha$-L-rhamnopyranosyl- $(1 \rightarrow 4)]-O-\alpha$ L-rhamnopyranosyl-( $1 \rightarrow 4)-O$ - $\alpha$-L-rhamnopyranosyl- $(1 \rightarrow 2)-\beta$-Dfucopyranoside, that was obtained along with three organic acids, $2 S$-methylbutyric, $n$-decanoic, and $n$-dodecanoic acids, upon alkaline hydrolysis of the crude jalapin fraction of the seeds of the plant. ${ }^{4,5)}$ Furthermore, we isolated four genuine jalapins, quamoclins I, II, III, and IV, from the above-mentioned fraction. ${ }^{4}$ In addition, we reported the component organic and glycosidic acids of the crude convolvulin fraction of the seeds. ${ }^{6,7)}$

In recent years, some ester-type dimers of resin glycosides have been isolated. ${ }^{8-12)}$ We therefore reexamined the constituents of the seeds to clarify whether ester-type dimers were present.

The powdered seeds of $Q$. pennata were extracted with methanol $(\mathrm{MeOH})$. This extract was suspended in $\mathrm{H}_{2} \mathrm{O}$ and then successively extracted with $n$-hexane and $n$-butanol $(\mathrm{BuOH})$ to afford a $n$-hexane-soluble fraction and a $\mathrm{BuOH}$ soluble fraction. The latter fraction was applied to Diaion

The authors declare no conflict of interest.
HP20, silica gel, Sephadex LH-20, and Chromatorex octadecyl silica (ODS) column chromatography, as well as HPLC on ODS to give four compounds (1-4).

Compound $\mathbf{1}$, tentatively named quamoclin $\mathrm{V}$, was obtained as an amorphous powder. High-resolution (HR)-negative-ion FAB-MS showed the molecular formula of 1 to be $\mathrm{C}_{49} \mathrm{H}_{84} \mathrm{O}_{24}$. The ${ }^{1} \mathrm{H}-\mathrm{NMR}$ spectrum of $\mathbf{1}$ exhibited signals due to one 2-methylbutyryl unit (Mba) $[\delta 2.48(1 \mathrm{H}, \mathrm{ddq}, J=7.0,7.0$, $7.0 \mathrm{~Hz}), 1.18(3 \mathrm{H}, \mathrm{d}, J=7.0 \mathrm{~Hz}), 0.92(3 \mathrm{H}, \mathrm{dd}, J=7.5,7.5 \mathrm{~Hz})]$, one primary methyl group $[\delta 0.97(3 \mathrm{H}, \mathrm{t}, J=7.0 \mathrm{~Hz})]$, and five anomeric protons $[\delta 6.35(1 \mathrm{H}, \mathrm{d}, J=1.5 \mathrm{~Hz}), 6.12(1 \mathrm{H}, \mathrm{d}$, $J=1.5 \mathrm{~Hz}), 5.92(1 \mathrm{H}, \mathrm{d}, J=1.0 \mathrm{~Hz}), 5.19(1 \mathrm{H}, \mathrm{d}, J=8.0 \mathrm{~Hz}), 4.77$ $(1 \mathrm{H}, \mathrm{d}, J=7.5 \mathrm{~Hz})]$. The ${ }^{13} \mathrm{C}-\mathrm{NMR}$ spectrum showed signals assignable to two carboxyl carbons $(\delta 176.3,174.4)$ and five anomeric carbons $(\delta 104.2,103.2,101.8,101.5,100.4)$. These ${ }^{1} \mathrm{H}$ - and ${ }^{13} \mathrm{C}$-NMR signals were assigned with the aid of ${ }^{1} \mathrm{H}-{ }^{1} \mathrm{H}$ correlation spectroscopy (COSY), heteronuclear multiplequantum coherence (HMQC), and heteronuclear multiple-bond correlation (HMBC) spectra (Tables 1 and 2). The abovementioned data suggested that 1 was composed of 1 mol each of 2-methylbutyric acid and quamoclinic acid A (5), and that the carboxyl group of the aglycone of $\mathbf{1}$ was also intramolecularly linked with a hydroxyl group of the sugar moiety to form a macrocyclic ester structure, as in already known jalapins. ${ }^{2}$ The presence of this structure was supported by the nonequivalent signals due to $\mathrm{H}_{2}-2$ of the convolvulinoloyl unit (Con) of 1 observed at $\delta 2.31(1 \mathrm{H}$, ddd, $J=3.0,10.0,13.5 \mathrm{~Hz})$ and $\delta 2.12$ $(1 \mathrm{H}, \mathrm{ddd}, J=3.0,7.5,13.5 \mathrm{~Hz})$, whereas 5 exhibited the equivalent signal due to $\mathrm{H}_{2}-2$ of Con at $\delta 2.51(2 \mathrm{H}, \mathrm{t}, J=7.3 \mathrm{~Hz})$ in the ${ }^{1} \mathrm{H}-\mathrm{NMR}$ spectrum. ${ }^{4}$

Comparing the chemical shifts of the ${ }^{1} \mathrm{H}-\mathrm{NMR}$ signals due to the sugar moieties between $\mathbf{1}$ and $\mathbf{5},{ }^{4)}$ remarkable acylation shifts $(\Delta \delta=\delta \mathbf{1}-\delta \mathbf{5})$ were observed in the signals due to $\mathrm{H}-3$ $(\Delta \delta=1.03)$ of the first rhamnosyl unit (Rha) and H-4 $(\Delta \delta=1.47)$ of the third rhamnosyl unit (Rha") in $\mathbf{1}$ (Table 1). Thus, the ester linkages could be located at the $\mathrm{OH}-3$ of Rha and the $\mathrm{OH}-4$ of Rha". The negative-ion FAB-MS of $\mathbf{1}$ exhibited fragment ion peaks at $m / z 893,825,517,389$, and 243, while 5 showed a 
Table 1. ${ }^{1} \mathrm{H}-\mathrm{NMR}$ Spectral Data for $\mathbf{1}-\mathbf{3}$ (in Pyridine- $d_{5}, 500 \mathrm{MHz}$ )

\begin{tabular}{|c|c|c|c|}
\hline & 1 & 2 & 3 \\
\hline Fuc-1 & $4.77 \mathrm{~d}(7.5)$ & $4.69 \mathrm{~d}(7.5)$ & $4.78 \mathrm{~d}(7.5)$ \\
\hline 2 & $4.50 \mathrm{dd}(7.5,9.0)$ & $4.14 \mathrm{dd}(7.5,9.5)$ & $4.48 \mathrm{dd}(7.5,9.0)$ \\
\hline 3 & $4.17 \mathrm{dd}(2.5,9.0)$ & $4.04 \mathrm{dd}(3.5,9.5)$ & $4.14 \mathrm{dd}(3.5,9.0)$ \\
\hline 4 & $3.91 \mathrm{~d}(2.5)$ & $3.95 \mathrm{~d}(3.5)$ & $3.94 \mathrm{~d}(3.5)$ \\
\hline 5 & $3.80 \mathrm{q}(6.5)$ & $3.72 \mathrm{q}(6.0)$ & 3.79 q (6.5) \\
\hline 6 & $1.51 \mathrm{~d}(6.5)$ & $1.48 \mathrm{~d}(6.0)$ & $1.52 \mathrm{~d}(6.5)$ \\
\hline Rha-1 & $6.35 \mathrm{~d}(1.5)$ & $5.49 \mathrm{~d}(1.5)$ & $6.22 \mathrm{~d}(1.5)$ \\
\hline 2 & $5.23 \mathrm{dd}(1.5,3.0)$ & $5.87 \mathrm{dd}(1.5,3.0)$ & $4.66 \mathrm{dd}(1.5,3.5)$ \\
\hline 3 & $5.62 \mathrm{dd}(3.0,9.5)$ & $4.99 \mathrm{dd}(3.0,9.5)$ & $4.60 \mathrm{dd}(3.5,9.5)$ \\
\hline 4 & $4.73 \mathrm{dd}(9.5,9.5)$ & 4.14 dd $(9.5,9.5)$ & $4.20 \mathrm{dd}(9.5,9.5)$ \\
\hline 5 & $4.96 \mathrm{dq}(9.5,6.5)$ & ca. 4.51 & $4.85 \mathrm{dq}(9.5,6.0)$ \\
\hline 6 & $1.55 \mathrm{~d}(6.5)$ & $1.67 \mathrm{~d}(6.5)$ & $1.60 \mathrm{~d}(6.0)$ \\
\hline Rha'-1 & $5.92 \mathrm{~d}(1.0)$ & $5.98 \mathrm{~d}(1.5)$ & $5.85 \mathrm{~d}(1.5)$ \\
\hline 2 & 4.75 br s & $5.11 \mathrm{dd}(1.5,2.5)$ & 5.19 br s \\
\hline 3 & $4.53 \mathrm{dd}(3.5,9.0)$ & $4.68 \mathrm{dd}(2.5,9.0)$ & $4.71 \mathrm{dd}(3.0,9.0)$ \\
\hline 4 & $4.39 \mathrm{dd}(9.0,9.0)$ & $4.48 \mathrm{dd}(9.0,9.0)$ & ca. 4.44 \\
\hline 5 & ca. 4.30 & $4.36 \mathrm{~m}$ & ca. 4.42 \\
\hline 6 & $1.55 \mathrm{~d}(6.0)$ & $1.63 \mathrm{~d}(6.5)$ & $1.60 \mathrm{~d}(6.0)$ \\
\hline Rha"-1 & $6.12 \mathrm{~d}(1.5)$ & $6.19 \mathrm{~d}(1.5)$ & $6.17 \mathrm{~d}(1.5)$ \\
\hline 2 & $4.87 \mathrm{dd}(1.5,3.5)$ & ca. 4.89 & $4.89 \mathrm{dd}(1.5,3.5)$ \\
\hline 3 & ca. 4.43 & ca. 4.53 & ca. 4.44 \\
\hline 4 & $5.68 \mathrm{dd}(9.0,9.0)$ & $5.72 \mathrm{dd}(9.5,9.5)$ & $5.69 \mathrm{dd}(9.5,9.5)$ \\
\hline 5 & ca. 4.28 & $4.35 \mathrm{~m}$ & $4.32 \mathrm{dq}(9.5,6.5)$ \\
\hline 6 & $1.32 \mathrm{~d}(6.5)$ & $1.34 \mathrm{~d}(6.5)$ & $1.32 \mathrm{~d}(6.5)$ \\
\hline Glc-1 & $5.19 \mathrm{~d}(8.0)$ & $5.12 \mathrm{~d}(7.5)$ & $5.20 \mathrm{~d}(8.0)$ \\
\hline 2 & $3.97 \mathrm{dd}(8.0,9.0)$ & $3.93 \mathrm{dd}(7.5,9.0)$ & $3.97 \mathrm{dd}(8.0,9.0)$ \\
\hline 3 & $4.16 \mathrm{dd}(9.0,9.0)$ & $4.08 \mathrm{dd}(9.0,9.0)$ & $4.16 \mathrm{dd}(9.0,9.0)$ \\
\hline 4 & $4.30 \mathrm{dd}(9.0,9.0)$ & $3.99 \mathrm{dd}(9.0,9.0)$ & $4.08 \mathrm{dd}(9.0,9.0)$ \\
\hline 5 & ca. 3.93 & $\begin{array}{c}3.78 \text { ddd }(2.5 \\
6.0,9.0)\end{array}$ & ca. 3.94 \\
\hline $6 a$ & ca. 4.46 & $\begin{array}{l}4.41 \mathrm{dd}(2.5 \\
12.0)\end{array}$ & $\begin{array}{c}4.53 \mathrm{dd}(2.0 \\
11.5)\end{array}$ \\
\hline $6 b$ & ca. 4.44 & $\begin{array}{l}4.07 \mathrm{dd}(6.0 \\
12.0)\end{array}$ & $\begin{array}{c}4.26 \mathrm{dd}(5.5 \\
11.5)\end{array}$ \\
\hline Con-2 & $\begin{array}{c}2.31 \mathrm{ddd}(3.0 \\
10.0,13.5)\end{array}$ & $\begin{array}{c}2.38 \text { ddd }(4.0 \\
8.5,14.5)\end{array}$ & $2.32 \mathrm{t}(7.5)$ \\
\hline 2 & $\begin{array}{c}2.12 \text { ddd }(3.0 \\
7.5,13.5)\end{array}$ & $\begin{array}{c}2.23 \text { ddd }(4.0 \\
8.5,14.5)\end{array}$ & \\
\hline 11 & $3.84 \mathrm{~m}$ & $3.83 \mathrm{dd}(5.0,5.0)$ & $4.00 \mathrm{~m}$ \\
\hline 14 & $0.97 \mathrm{t}(7.0)$ & $0.91 \mathrm{t}(7.5)$ & $1.01 \mathrm{t}(7.5)$ \\
\hline $\mathrm{OCH}_{3}$ & & & $3.62 \mathrm{~s}$ \\
\hline Mba-2 & $\begin{array}{c}2.48 \text { ddq (7.0) } \\
7.0,7.0)\end{array}$ & $\begin{array}{c}2.52 \text { ddd (7.0) } \\
7.0,7.0)\end{array}$ & $\begin{array}{c}2.50 \mathrm{ddq}(7.0 \\
7.0,7.0)\end{array}$ \\
\hline 3 & $1.77 \mathrm{~m}$ & $1.79 \mathrm{~m}$ & ca. 1.78 \\
\hline 3 & ca. 1.47 & ca. 1.48 & ca. 1.49 \\
\hline 4 & $0.92 \mathrm{dd}(7.5,7.5)$ & $0.94 \mathrm{dd}(7.5,7.5)$ & $0.93 \mathrm{dd}(7.5,7.5)$ \\
\hline 5 & $1.18 \mathrm{~d}(7.0)$ & $1.20 \mathrm{~d}(7.0)$ & $1.19 \mathrm{~d}(7.0)$ \\
\hline
\end{tabular}

$\delta$ in ppm from TMS (coupling constants $(J)$ in $\mathrm{Hz}$ are given in parentheses). Fuc fucopyranosyl unit; Rha, rhamnopyranosyl unit; Glc, glucopyranosyl unit; Con, convolvulinoloyl unit; Mba, 2-methylbutyryl unit.

peak at $\mathrm{m} / \mathrm{z} 535$ [244 (convolvulinolic acid) $+2 \times 146$ (6-deoxyhexose unit) $-\mathrm{H}]^{-}$in place of that at $\mathrm{m} / \mathrm{z} 517$. The difference of 18 mass units suggested that the ester linkage of Con should be placed in $\mathrm{Rha}^{4)}$ (Fig. 1). In addition, the HMBC spectrum of 1 showed a key cross-peak between H-4 of Rha" and C-1 of Mba. Therefore, the ester linkages of Con and Mba were determined to be located at OH-3 of Rha and OH-4 of Rha", respectively. Taking the $J$ values of signals due to anomeric and methine protons of the sugar moieties into account, the conformations of rhamnopyranosyl units were concluded to be

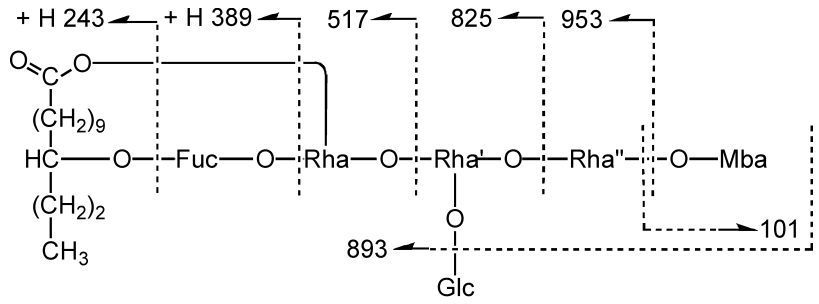

Fuc, fucopyranosyl; Rha, rhamnopyranosyl; Glc, glucopyranosyl; Mba, 2-methylbutyryl

Fig. 1. Fragment Ions Observed in the Negative-Ion FAB-MS of $\mathbf{1}$

${ }^{1} \mathrm{C}_{4}$ and those of the fucopyranosyl and glucopyranosyl units were concluded to be ${ }^{4} \mathrm{C}_{1}$. The configuration of the component 2-methylbutyric acid of the crude jalapin fraction of this plant had been previously determined to be $S .{ }^{4)}$ Consequently, the structure of 1 was characterized as $11 S$-convolvulinolic acid $11-O-\beta$-D-glucopyranosyl-(1 $\rightarrow 3)-O$-[4- $O-2 S$-methylbutyryl- $\alpha$ L-rhamnopyranosyl-( $1 \rightarrow 4)]-O$ - $\alpha$-L-rhamnopyranosyl-( $1 \rightarrow 4)-O$ $\alpha$-L-rhamnopyranosyl-( $1 \rightarrow 2)-\beta$-D-fucopyranoside, intramolecular $1,3^{\prime \prime}$-ester, as shown in Fig. 2.

Compound 2, tentatively named quamoclin VI, was obtained as an amorphous powder, and its molecular formula was the same as that of $\mathbf{1}$. The negative-ion FAB-MS of $\mathbf{2}$ also showed the same fragment ion peaks as those of $\mathbf{1}$ at $\mathrm{m} / \mathrm{z} 517$, 389 , and 243 . The ${ }^{1} \mathrm{H}-\mathrm{NMR}$ spectrum of $\mathbf{2}$, which was similar to that of $\mathbf{1}$, displayed signals due to one each of Mba and $\mathbf{5}$ (Table 1). From the foregoing data, 2 was considered to be a positional isomer of $\mathbf{1}$ as to the ester linkage. A comparison of the ${ }^{1} \mathrm{H}-\mathrm{NMR}$ spectrum of $\mathbf{2}$ with that of $\mathbf{1}$ indicated a downfield shift $(0.64 \mathrm{ppm})$ of signal due to $\mathrm{H}-2$ of Rha and an upfield shift $(0.63 \mathrm{ppm})$ of signal due to $\mathrm{H}-3$ of Rha, and the resonance of $\mathrm{H}-4$ of Rha" was imposable on that of $\mathbf{1}$. In addition, the HR-positive-ion FAB-MS of the peracetate (2a) of 2 revealed a fragment ion peak at $m / z$ 315.1444, which was assigned to the fragment ion of the 4-O-2-methylbutyryl-2,3-Odiacetyl-rhamnopyranosyl unit. ${ }^{13)}$ Consequently, 2 was determined to be a positional isomer of $\mathbf{1}$, in which Con of $\mathbf{2}$ was at the OH-2 of Rha rather than at the OH-3 of Rha.

Compound 3, tentatively named quamoclin VII, was obtained as an amorphous powder. HR-negative-ion FAB-MS indicated the molecular formula of 3 to be $\mathrm{C}_{50} \mathrm{H}_{88} \mathrm{O}_{25}$. The ${ }^{1} \mathrm{H}-\mathrm{NMR}$ spectrum of $\mathbf{3}$ showed signals due to one $\mathrm{Mba}[\delta$ $2.50(1 \mathrm{H}, \mathrm{ddq}, J=7.0,7.0,7.0 \mathrm{~Hz}), 1.19(3 \mathrm{H}, \mathrm{d}, J=7.0 \mathrm{~Hz})$, $0.93(3 \mathrm{H}, \mathrm{dd}, J=7.5,7.5 \mathrm{~Hz})]$, one methoxy group $[\delta 3.62(3 \mathrm{H}$, $\mathrm{s})]$, one primary methyl group $[\delta 1.01(3 \mathrm{H}, \mathrm{t}, J=7.5 \mathrm{~Hz})]$, two equivalent methylene protons $[\delta 2.32(2 \mathrm{H}, \mathrm{t}, J=7.5 \mathrm{~Hz})]$ adjacent to a carbonyl group, five anomeric protons $[\delta 6.22(1 \mathrm{H}$, d, $J=1.5 \mathrm{~Hz}), 6.17(1 \mathrm{H}, \mathrm{d}, J=1.5 \mathrm{~Hz}), 5.85(1 \mathrm{H}, \mathrm{d}, J=1.5 \mathrm{~Hz})$, $5.20(1 \mathrm{H}, \mathrm{d}, J=8.0 \mathrm{~Hz}), 4.78(1 \mathrm{H}, \mathrm{d}, J=7.5 \mathrm{~Hz})]$, and four secondary methyl groups $[\delta 1.60(3 \mathrm{H}, \mathrm{d}, J=6.0 \mathrm{~Hz}), 1.60(3 \mathrm{H}$, $\mathrm{d}, J=6.0 \mathrm{~Hz}), 1.52(3 \mathrm{H}, \mathrm{d}, J=6.5 \mathrm{~Hz}), 1.32(3 \mathrm{H}, \mathrm{d}, J=6.5 \mathrm{~Hz})]$ assignable to $\mathrm{H}_{3}-6$ of the 6-deoxyhexosyl units (Table 1). The ${ }^{13} \mathrm{C}-\mathrm{NMR}$ spectrum of $\mathbf{3}$ yielded signals due to five anomeric carbons $(\delta 105.6,103.5,103.0,101.5,101.1)$ and two carboxyl carbons $(\delta 176.3,174.0)$ (Table 2$)$. These NMR signals were assigned in detail with the aid of 2D-NMR techniques as was done for 1; the assigned data indicated that 3 was composed of $1 \mathrm{~mol}$ each of Mba and methyl ester of $\mathbf{5}$. When compared with those of $\mathbf{5}$, the ${ }^{1} \mathrm{H}-\mathrm{NMR}$ signals due to the 

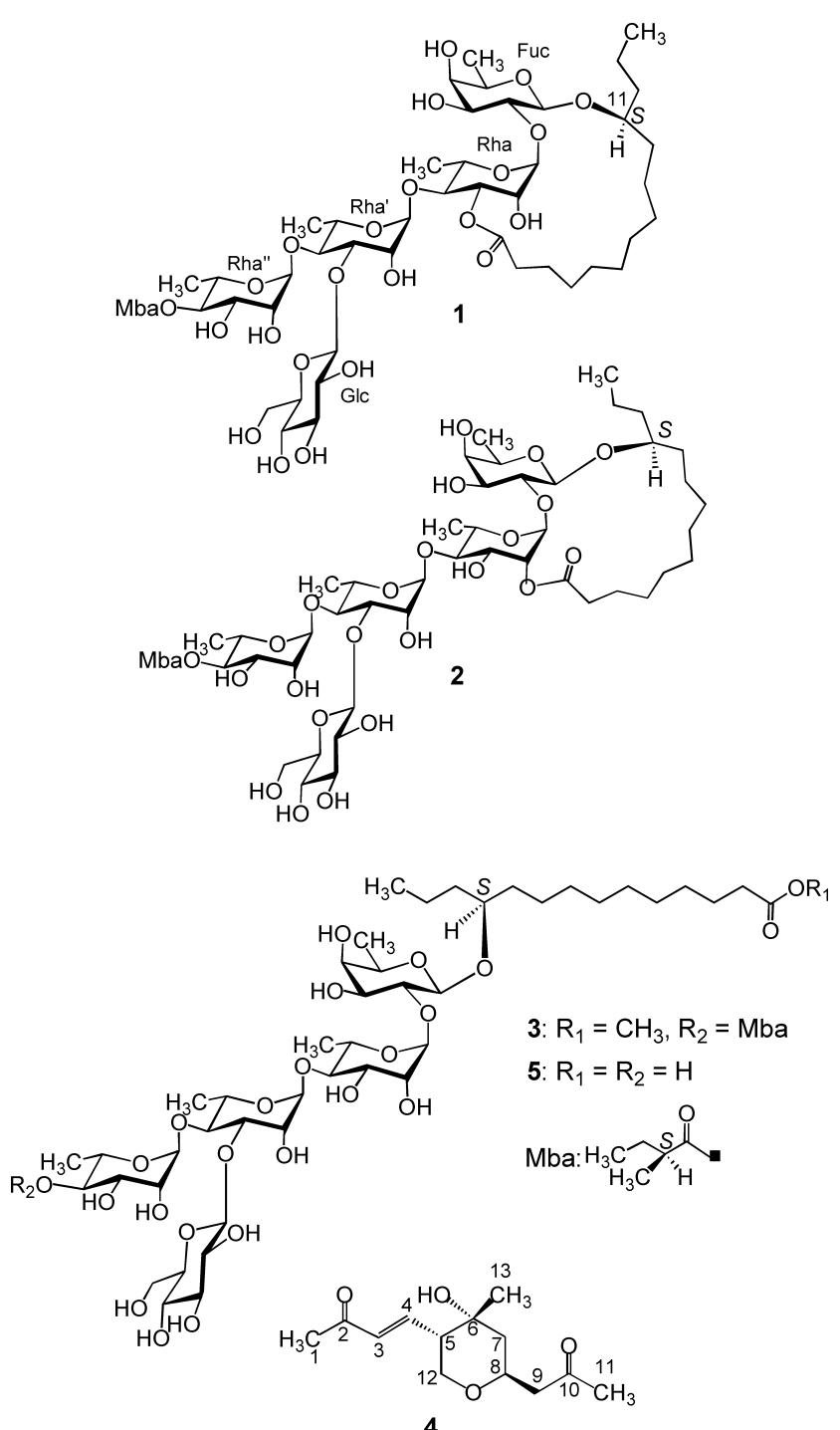

Fig. 2. Structures of $\mathbf{1}-\mathbf{5}$

sugar moiety of $\mathbf{3}$ showed a downfield shift (1.48 ppm) of signal due to H-4 of Rha," and the chemical shifts of other signals were almost same as those of $\mathbf{5}$. Consequently, the structure of $\mathbf{3}$ was defined as methyl $11 S$-convolvulinolate $11-O$ - $\beta$-D-glucopyranosyl- $(1 \rightarrow 3)-O$-[4- $O-2 S$-methylbutyryl- $\alpha$ L-rhamnopyranosyl-(1 $\rightarrow 4)]-O-\alpha$-L-rhamnopyranosyl- $(1 \rightarrow 4)-O$ $\alpha$-L-rhamnopyranosyl-( $1 \rightarrow 2)-\beta$-D-fucopyranoside, as shown in Fig. 2.

Compound 4, tentatively named quamopyran, was obtained as an amorphous powder, and the molecular formula was determined to be $\mathrm{C}_{13} \mathrm{H}_{20} \mathrm{O}_{4}$ by HR-positive-ion FAB-MS. The ${ }^{1} \mathrm{H}-\mathrm{NMR}$ spectrum of $\mathbf{4}$ showed signals due to two transcoupled olefinic protons $[\delta 7.12(1 \mathrm{H}, \mathrm{dd}, J=9.5,16.5 \mathrm{~Hz}), 6.34$ $(1 \mathrm{H}, \mathrm{d}, J=16.5 \mathrm{~Hz})]$, one oxygenated methine proton $[\delta 4.69$ $(1 \mathrm{H}, \mathrm{m})]$, two oxygenated methylene protons $[\delta 4.08(1 \mathrm{H}, \mathrm{dd}$, $J=11.0,11.0 \mathrm{~Hz}), 3.76(1 \mathrm{H}, \mathrm{dd}, J=4.5,11.0 \mathrm{~Hz})]$, and three tertiary methyl groups $[\delta 2.15(3 \mathrm{H}, \mathrm{s}), 2.15(3 \mathrm{H}, \mathrm{s}), 1.32(3 \mathrm{H}$, $\mathrm{s})$ ]. The ${ }^{13} \mathrm{C}-\mathrm{NMR}$ spectrum of 4 showed 13 carbon signals, which were composed of signals due to two carbonyl carbons $(\delta 206.5,197.6)$, two olefinic carbons ( $\delta$ 144.9, 134.6), one oxygenated quaternary carbon $(\delta 68.1)$, one oxygenated methine carbon $(\delta$ 70.2), one oxygenated methylene carbon
( $\delta$ 67.3), two methylene carbons ( $\delta$ 50.1, 45.4), one methine carbon $(\delta 50.4)$, and three methyl carbons $(\delta 30.5,29.4,26.7)$. These NMR signals were assigned with the aid of 2D-NMR techniques, as in the case of $\mathbf{1}$ (Table 3), and the planar structure of $\mathbf{4}$ could be determined and is illustrated in Fig. 3. The relative stereochemistry was defined on the basis of the nuclear Overhauser and exchange spectroscopy (NOESY) spectrum, in which key correlations were observed between $\mathrm{H}-5$ and $\mathrm{H}_{3}-13, \mathrm{H}-7 \mathrm{~b}$ and $\mathrm{H}_{3}-13$, and $\mathrm{H}-8$ and $\mathrm{H}-12 \mathrm{a}$, and by analysis of the coupling constants $\left(J_{\mathrm{H}-5-\mathrm{H}-12 \mathrm{a}} 11.0 \mathrm{~Hz} ; J_{\mathrm{H}-7 \mathrm{~b}-\mathrm{H}-8}\right.$ $11.5 \mathrm{~Hz}$ ) between $\mathrm{H}-5$ and $\mathrm{H}-12 \mathrm{a}$ and between $\mathrm{H}-7 \mathrm{~b}$ and $\mathrm{H}-8$ in the ${ }^{1} \mathrm{H}-\mathrm{NMR}$ spectrum (Fig. 4). These data indicated that the relative configurations at $\mathrm{C}-5, \mathrm{C}-6$, and $\mathrm{C}-8$ were $S^{*}, R^{*}$, and $S^{*}$, respectively. Furthermore, the large pyridine-induced downfield shifts $\left(\Delta \delta=\delta \mathrm{CDCl}_{3}-\delta\right.$ pyridine- $\left.d_{5}\right)$ of the ${ }^{1} \mathrm{H}-\mathrm{NMR}$ signals due to H-4 ( $\Delta \delta=-0.39), \mathrm{H}-8(\Delta \delta=-0.48)$, and $\mathrm{H}-12 \mathrm{a}$ ( $\Delta \delta=-0.34)$ were observed (Fig. 3). Since the hydroxyl group forms a hydrogen bond with the nitrogen atom of pyridine, pyridine-induced deshielding effects are anticipated to be observed in protons in the vicinity of the hydroxyl group. ${ }^{14)}$ These deshielding effects supported the foregoing configurations. Consequently, the structure of $\mathbf{4}$ was concluded to be (E)-4-((rel. 3R,4S,6R)-4-hydroxy-4-methyl-6-(2-oxopropyl)tetrahydro-2 $H$-pyran-3-yl)but-3-en-2-one.

To the best of our knowledge, 1-4 are new compounds, and $\mathbf{1}$ and $\mathbf{2}$ correspond to the dedodecanoyl derivatives of quamoclins II and I, respectively. Though three methyl esters of nonmacrocyclic resin glycosides, like $\mathbf{3}$, have been previously reported as natural constituents, ${ }^{15,16)} \mathbf{3}$ was considered to be an artifact produced from $\mathbf{1}$ and/or $\mathbf{2}$ during extraction and isolation procedures, because the glycosidic acid of $\mathbf{3}$ was different from those seen in the crude convolvilin fraction of the seeds of $Q$. pennata. We could not obtain ester-type dimers from these seeds.

\section{Experimental}

General Procedure Optical rotations were determined with a JASCO DIP-1000 KYU digital polarimeter (JASCO, Tokyo, Japan). MS data were collected using a JEOL JMS-700 mass spectrometer (JEOL, Tokyo, Japan). ${ }^{1} \mathrm{H}-$ and ${ }^{13} \mathrm{C}-\mathrm{NMR}$ spectra were recorded by using JEOL ECA 500 spectrometer (JEOL), and chemical shifts were given on a $\delta$ (ppm) scale with tetramethylsilane (TMS) as an internal standard. Diaion HP20 (Mitsubishi Chemical Industries Co., Ltd., Tokyo, Japan), silica gel 60 (Merck, Art. 9385; Merck, Darmstadt, Germany), Sephadex LH-20 (Pharmacia Fine Chemicals, Uppsala, Sweden), and Chromatorex ODS (Fuji Silysia Chemical, Ltd., Aichi, Japan) were used for column chromatography. HPLC separation was performed on a Shimadzu LC-10AS micro pump (Shimadzu, Kyoto, Japan) with Shimadzu RID-10A RI detector (Shimadzu). For HPLC column chromatography, COSMOSIL 5C18-AR-II (Nacalai Tesque, Inc., Kyoto, Japan, $20 \mathrm{~mm}$ i.d. $\times 250 \mathrm{~mm}$ ) was used.

Plant Material The seeds of Q. pennata were purchased from Heiwaen, a gardening shop in Nara Prefecture, Japan in 1990 and identified by Professor Kazumoto Miyahara, Faculty of Pharmaceutical Sciences, Setsunan University. A voucher specimen (QP1990) has been deposited at the laboratory of Natural Products Chemistry, School of Agriculture, Tokai University.

Extraction and Isolation The powdered seeds of $Q$. 
Table 2. ${ }^{13} \mathrm{C}-\mathrm{NMR}$ Spectral Data for $\mathbf{1}-\mathbf{3}$ (in Pyridine- $d_{5}, 125 \mathrm{MHz}$ )

\begin{tabular}{|c|c|c|c|c|c|c|c|}
\hline & 1 & 2 & 3 & & 1 & 2 & 3 \\
\hline Fuc-1 & 101.8 & 104.1 & 101.1 & Glc-1 & 104.2 & 105.3 & 105.6 \\
\hline 2 & 73.5 & 79.8 & 75.2 & 2 & 75.2 & 75.1 & 75.1 \\
\hline 3 & 76.7 & 73.4 & 76.6 & 3 & 78.4 & 78.4 & 78.5 \\
\hline 4 & 73.6 & 72.9 & 73.5 & 4 & 71.2 & 71.8 & 71.7 \\
\hline 5 & 71.2 & 70.8 & 71.2 & 5 & 78.0 & 78.2 & 78.5 \\
\hline 6 & 17.2 & 17.3 & 17.2 & 6 & 62.5 & 62.9 & 62.9 \\
\hline Rha-1 & 100.4 & 98.3 & 101.5 & Agl-1 & 174.4 & 173.1 & 174.0 \\
\hline 2 & 69.9 & 73.7 & 72.6 & 2 & 34.7 & 34.2 & 34.2 \\
\hline 3 & 78.9 & 69.8 & 72.6 & 11 & 79.5 & 82.0 & 77.6 \\
\hline 4 & 74.2 & 81.8 & 82.7 & 14 & 14.6 & 14.6 & 14.6 \\
\hline 5 & 67.9 & 69.1 & 67.5 & $\mathrm{CH}_{2}$ & 37.7 & 36.6 & 37.8 \\
\hline 6 & 19.3 & 19.2 & 18.8 & $\mathrm{CH}_{2}$ & 35.2 & 33.3 & 34.3 \\
\hline $\mathrm{Rha}^{\prime}-1$ & 101.5 & 103.5 & 103.5 & $\mathrm{CH}_{2}$ & 30.4 & 28.2 & 30.3 \\
\hline 2 & 71.2 & 71.8 & 71.9 & $\mathrm{CH}_{2}$ & 28.4 & 27.6 & 30.1 \\
\hline 3 & 82.5 & 82.3 & 82.8 & $\mathrm{CH}_{2}$ & 27.6 & 27.6 & 29.9 \\
\hline 4 & 78.9 & 79.0 & 79.2 & $\mathrm{CH}_{2}$ & 26.9 & 27.2 & 29.7 \\
\hline 5 & 68.2 & 68.7 & 68.4 & $\mathrm{CH}_{2}$ & 26.8 & 27.2 & 29.5 \\
\hline 6 & 18.7 & 19.0 & 18.9 & $\mathrm{CH}_{2}$ & 26.3 & 25.0 & 25.8 \\
\hline Rha"-1 & 103.2 & 103.0 & 103.0 & $\mathrm{CH}_{2}$ & 23.5 & 23.5 & 25.3 \\
\hline 2 & 72.4 & 72.6 & 72.6 & $\mathrm{CH}_{2}$ & 18.4 & 18.5 & 18.7 \\
\hline 3 & 70.2 & 70.3 & 70.2 & $\mathrm{OCH}_{3}$ & & & 51.2 \\
\hline 4 & 75.0 & 75.2 & 75.1 & Mba-1 & 176.3 & 176.3 & 176.3 \\
\hline 5 & 68.0 & 68.0 & 67.9 & 2 & 41.5 & 41.5 & 41.5 \\
\hline \multirow[t]{3}{*}{6} & 17.9 & 17.9 & 17.9 & 3 & 27.1 & 27.1 & 27.1 \\
\hline & & & & 4 & 11.7 & 11.7 & 11.7 \\
\hline & & & & 5 & 17.0 & 17.0 & 17.0 \\
\hline
\end{tabular}

$\delta$ in ppm from TMS. Fuc, fucopyranosyl unit; Glc, glucopyranosyl unit; Rha, rhamnopyranosyl unit; Con, convolvulinoloyl unit; Mba, 2-methylbutyryl unit.

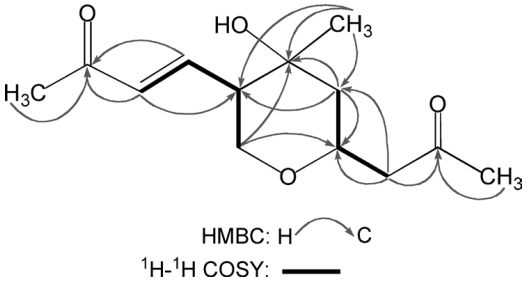

Fig. 3. Connectivities Elucidated by the ${ }^{1} \mathrm{H}-{ }^{1} \mathrm{H}$ COSY Spectrum (Bold Lines) and ${ }^{1} \mathrm{H}-{ }^{13} \mathrm{C}$ Long-Range Correlations (Arrows) Observed in the HMBC Spectrum of 4 (in Pyridine- $d_{5}, 500 \mathrm{MHz}$ )

pennata $(1102.2 \mathrm{~g})$ were extracted with $\mathrm{MeOH}(4 \mathrm{~L})$ at room temperature for two weeks, and the solvent was removed in vacuo to yield a $\mathrm{MeOH}$ extract $(109.3 \mathrm{~g})$. The $\mathrm{MeOH}$ extract $(109.2 \mathrm{~g})$ was suspended in $\mathrm{H}_{2} \mathrm{O}(400 \mathrm{~mL})$ and then successively extracted with $n$-hexane $(200 \mathrm{~mL} \times 2)$ and $\mathrm{BuOH}$ $(300 \mathrm{~mL} \times 3)$ to afford a $n$-hexane-soluble fraction (fr.) $(4.605 \mathrm{~g})$ and a BuOH-soluble fr. (69.06g). A part (67.97g) of the $\mathrm{BuOH}$-soluble fr. was applied to Diaion HP20 column chromatography using gradient mixtures of $\mathrm{H}_{2} \mathrm{O}-\mathrm{MeOH}(50 \%$ $\mathrm{MeOH}, 70 \% \mathrm{MeOH}, 90 \% \mathrm{MeOH}, 95 \% \mathrm{MeOH}, 100 \% \mathrm{MeOH})$ and acetone as eluents to give fractions (frs.) 1-6. Fraction 2 $(3.240 \mathrm{~g})$ was chromatographed over silica gel column using gradient mixtures of $\mathrm{CHCl}_{3}-\mathrm{MeOH}-\mathrm{H}_{2} \mathrm{O}(14: 2: 0.1,10: 2: 0.1$, $8: 2: 0.2,7: 3: 0.5,6: 4: 1)$ as eluents to give frs. 2.1-2.6. Fraction $2.2(296 \mathrm{mg})$ was subjected to HPLC with $45 \% \mathrm{MeOH}$ as eluent to furnish $4(11 \mathrm{mg})$ and frs. 2.2.1-2.2.4. Fraction 3 (50.34g) was chromatographed over Sephadex LH-20 column with $\mathrm{MeOH}$ as eluent to afford frs. 3.1-3.4. Fraction 3.3

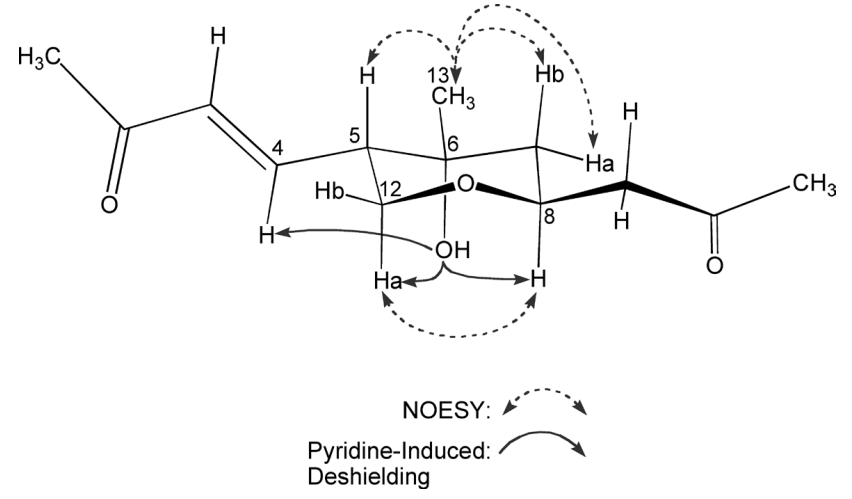

Fig. 4. Key NOE Correlations Observed in the NOESY Spectrum (in Pyridine- $d_{5}, 500 \mathrm{MHz}$ ) and Pyridine-Induced Deshieldings for 4

(41.28g) was suspended in $\mathrm{H}_{2} \mathrm{O}(300 \mathrm{~mL})$ and then successively extracted with ethyl acetate $(300 \mathrm{~mL} \times 3)$ and $\mathrm{BuOH}$ $(300 \mathrm{~mL} \times 3)$ to afford fr. 3.3 .1 (jalapin fr., 6.578 g), fr. 3.3.2 (convolvulin fr., $33.40 \mathrm{~g}$ ), and fr. 3.3.3. A part $(6.370 \mathrm{~g})$ of fr. 3.3.1 was subjected to Chromatorex ODS column chromatography using gradient mixtures of $\mathrm{H}_{2} \mathrm{O}-\mathrm{MeOH}(70 \% \mathrm{MeOH}$, $80 \% \mathrm{MeOH}, 90 \% \mathrm{MeOH}, 100 \% \mathrm{MeOH})$ as eluents to give frs. 3.3.1.1-3.3.1.19. Fraction 3.3.1.8 (902 mg) was chromatographed over silica gel column with hexane-acetone $(1: 1)$ as eluent to give frs. 3.3.1.8.1-3.3.1.8.3. Fraction 3.3.1.8.3 (216 mg) was subjected to silica gel column chromatography using gradient mixtures of $\mathrm{CHCl}_{3}-\mathrm{MeOH}-\mathrm{H}_{2} \mathrm{O}(14: 2: 0.1,10: 2: 0.1,8: 2: 0.2$, $7: 3: 0.5,6: 4: 1)$ as eluents to afford frs. 3.3.1.8.3.1-3.3.1.8.3.4. Fraction 3.3.1.8.3.3 (36 mg) was subjected to HPLC with $80 \%$ 
Table 3. ${ }^{1} \mathrm{H}$ - and ${ }^{13} \mathrm{C}-\mathrm{NMR}$ Spectral Data for 4

\begin{tabular}{|c|c|c|c|}
\hline & ${ }^{1} \mathrm{H}^{a)}$ & ${ }^{1} \mathrm{H}^{b)}$ & ${ }^{13} \mathrm{C}^{c)}$ \\
\hline 1 & $2.15 \mathrm{~s}$ & $2.27^{d)}$ & 30.5 \\
\hline 2 & & & 197.6 \\
\hline 3 & $6.34 \mathrm{~d}(16.5)$ & $6.16 \mathrm{~d}(16.0)$ & 134.6 \\
\hline 4 & $7.12 \mathrm{dd}(9.5,16.5)$ & $6.73 \mathrm{dd}(9.0,16.0)$ & 144.9 \\
\hline 5 & $\begin{array}{l}2.43 \text { ddd }(4.5,9.5 \\
11.0)\end{array}$ & $\begin{array}{l}2.35 \text { ddd }(5.0,9.0 \\
11.0)\end{array}$ & 50.4 \\
\hline 6 & & & 68.1 \\
\hline $7 \mathrm{a}$ & $1.89 \mathrm{dd}(2.0,13.0)$ & 1.70 dd $(1.5,13.5)$ & 45.4 \\
\hline $7 b$ & $\begin{array}{l}1.45 \text { dd }(11.5 \text {, } \\
13.0)\end{array}$ & $\begin{array}{l}1.42 \mathrm{dd}(11.5 \\
13.5)\end{array}$ & \\
\hline 8 & $4.69 \mathrm{~m}$ & $4.21 \mathrm{~m}$ & 70.2 \\
\hline $9 \mathrm{a}$ & $2.80 \mathrm{dd}(8.0,15.5)$ & $2.67 \mathrm{dd}(7.5,15.5)$ & 50.1 \\
\hline $9 b$ & $2.56 \mathrm{dd}(5.0,15.5)$ & $2.45 \mathrm{dd}(5.0,15.5)$ & \\
\hline 10 & & & 206.5 \\
\hline 11 & $2.15 \mathrm{~s}$ & $2.19^{d)}$ & 26.7 \\
\hline $12 \mathrm{a}$ & $\begin{array}{l}4.08 \text { dd }(11.0, \\
11.0)\end{array}$ & $\begin{array}{l}3.74 \text { dd }(11.0, \\
11.0)\end{array}$ & 67.3 \\
\hline $12 b$ & $3.76 \mathrm{dd}(4.5,11.0)$ & $3.63 \mathrm{dd}(5.0,11.0)$ & \\
\hline 13 & $1.32 \mathrm{~s}$ & $1.21 \mathrm{~s}$ & 29.4 \\
\hline
\end{tabular}

$\delta$ in ppm from TMS (coupling constants $(J)$ in $\mathrm{Hz}$ are given in parentheses). $a$ ) In pyridine- $d_{5}, 500 \mathrm{MHz} ; b$ ) in $\left.\mathrm{CDCl}_{3}, 500 \mathrm{MHz} ; c\right)$ in pyridine- $d_{5}, 125 \mathrm{MHz} ; d$ ) Assignments may be interchanged.

$\mathrm{MeOH}$ as eluent to furnish $\mathbf{3}(5 \mathrm{mg})$. The chromatography of fr. 3.3.1.17 $(383 \mathrm{mg})$ on silica gel column using gradient mixtures of hexane-acetone $(50: 1,20: 1,5: 1,2: 1,1: 5)$ as eluents gave frs. 3.3.1.17.1-3.3.1.17.14. HPLC of fr. 3.3.1.17.13 $(75 \mathrm{mg})$ with $90 \% \mathrm{MeOH}$ as eluent yielded $2(5 \mathrm{mg})$. Fractions 3.4 (7.663 g) and 3.3.1.15 (3.095 g) were chromatographed over silica gel column using gradient mixtures of $\mathrm{CHCl}_{3}-\mathrm{MeOH}-$ $\mathrm{H}_{2} \mathrm{O}(14: 2: 0.1,10: 2: 0.1,8: 2: 0.2,7: 3: 0.5,6: 4: 1)$ as eluents to give frs. 3.4.1-3.4.12. Fraction $3.4 .6(497 \mathrm{mg})$ was subjected to HPLC with $80 \% \mathrm{MeOH}$ as eluent to furnish $1(7 \mathrm{mg})$ and 3 (8 mg).

Quamoclin V (1): Amorphous powder. $[\alpha]_{\mathrm{D}}^{25}-60.4^{\circ}(c=0.5$, $\mathrm{MeOH})$. Negative-ion FAB-MS $m / z: 1055[\mathrm{M}-\mathrm{H}]^{-}, 953$ [1055-102 (2-methylbutyric acid) $]^{-}, 893$ [1055-162 (hexosyl unit) $]^{-}, 825$ [1055-230 (2-methylbutyrylrhamnosyl unit)] $]^{-}, 517$ $[825-162-146]^{-}, 389$ [517-128 (6-deoxyhexosyl unit $\left.\left.-\mathrm{H}_{2} \mathrm{O}\right)\right]^{-}$, 243 [389-146] $]^{-}$. HR-negative-ion FAB-MS $m / z$ : 1055.5298 (Calcd for $\mathrm{C}_{49} \mathrm{H}_{83} \mathrm{O}_{24}$ : 1055.5274). ${ }^{1} \mathrm{H}-\mathrm{NMR}$ spectral data: see Table $1 .{ }^{13} \mathrm{C}-\mathrm{NMR}$ spectral data: see Table 2.

Quamoclin VI (2): Amorphous powder. $[\alpha]_{\mathrm{D}}^{17}-10.1^{\circ}$ $\left(c=0.6\right.$, pyridine). Positive-ion FAB-MS $m / z: 1079[\mathrm{M}+\mathrm{Na}]^{+}$. HR-positive-ion FAB-MS $m / z$ : $1079.5276[\mathrm{M}+\mathrm{Na}]^{+}$(Calcd for $\mathrm{C}_{49} \mathrm{H}_{84} \mathrm{O}_{24} \mathrm{Na}$ : 1079.5250). Negative-ion FAB-MS $\mathrm{m} / \mathrm{z}$ : $1055[\mathrm{M}-\mathrm{H}]^{-}, \quad 953[1055-102]^{-}, 893[1055-162]^{-}, 825$ $[1055-230]^{-}, \quad 517[825-162-146]^{-}, \quad 389[517-128]^{-}, 243$ $[389-146]^{-}$. ${ }^{1} \mathrm{H}-\mathrm{NMR}$ spectral data: see Table $1 .{ }^{13} \mathrm{C}-\mathrm{NMR}$ spectral data: see Table 2 .

Quamoclin VII (3): Amorphous powder. $[\alpha]_{\mathrm{D}}^{25}-54.5^{\circ}$ $(c=0.4, \mathrm{MeOH})$. Negative-ion FAB-MS $m / z: 1087[\mathrm{M}-\mathrm{H}]^{-}$, 1003 [1087-84 (2-methylbutyryl unit)] , 925 [1187-162] ${ }^{-}, 857$ $[1003-146]^{-}, 695[857-162]^{-}, 549[695-146]^{-}$. HR-negative- ion FAB-MS $m / z$ : 1087.5551 (Calcd for $\mathrm{C}_{50} \mathrm{H}_{87} \mathrm{O}_{25}$ : 1087.5537). ${ }^{1} \mathrm{H}-\mathrm{NMR}$ spectral data: see Table $1 .{ }^{13} \mathrm{C}-\mathrm{NMR}$ spectral data: see Table 2.

Quamopyran (4): Amorphous powder. $[\alpha]_{\mathrm{D}}^{15}-20.0^{\circ}(c=0.4$, $\mathrm{MeOH})$. HR-positive-ion FAB-MS $m / z: 263.1264[\mathrm{M}+\mathrm{Na}]^{+}$ (Calcd for $\mathrm{C}_{13} \mathrm{H}_{20} \mathrm{O}_{4} \mathrm{Na}$ : 263.1260). ${ }^{1} \mathrm{H}$ - and ${ }^{13} \mathrm{C}-\mathrm{NMR}$ spectral data: see Table 3.

Acetylation of 2 Compound $\mathbf{2}(1 \mathrm{mg})$ was dissolved in acetic anhydride-pyridine $(1: 1,0.5 \mathrm{~mL})$, and the solution was left to stand at room temperature overnight. After removal of the reagent under an $\mathrm{N}_{2}$ stream, the residue was partitioned between ether $(1 \mathrm{~mL} \times 3)$ and $\mathrm{H}_{2} \mathrm{O}(1 \mathrm{~mL})$. The ether layer was concentrated to afford an acetate $(\mathbf{2 a}, 1 \mathrm{mg})$ of $\mathbf{2}$.

Compound 2a: Amorphous powder. Positive-ion FAB-MS $m / z: 1499[\mathrm{M}+\mathrm{Na}]^{+}, 833,627,485,331,315$. Negative-ion FAB-MS $m / z$ : $1475[\mathrm{M}-\mathrm{H}]^{-}, 1433,1391,1349,473,431$, 389. HR-positive-ion FAB-MS $m / z$ : 1499.6296 (Calcd for $\mathrm{C}_{69} \mathrm{H}_{104} \mathrm{O}_{34} \mathrm{Na}$ : 1499.6306), 315.1444 (Calcd for $\mathrm{C}_{15} \mathrm{H}_{23} \mathrm{O}_{7}$ : 315.1444). ${ }^{1} \mathrm{H}-\mathrm{NMR}$ spectral data (in $\mathrm{CDCl}_{3}, 500 \mathrm{MHz}$ ) $\delta$ : 2.20, 2.17, 2.10, 2.08, 2.07, 2.04, 2.02, 2.01, 1.99, 1.96 (each $3 \mathrm{H}, \mathrm{s}, \mathrm{COCH}_{3}$ )

Acknowledgment We express our appreciation to $\mathrm{Mr}$. H. Harazono of Fukuoka University for measurement of the FAB-MS.

\section{References}

1) Mayer W., Justus Liebigs Ann. Chem., 95, 129-176 (1855).

2) Ono M., Nakagawa K., Kawasaki T., Miyahara K., Chem. Pharm. Bull., 41, 1925-1932 (1993).

3) Ono M., Takigawa A., Mineno T., Yoshimitsu H., Nohara T., Ikeda T., Fukuda-Teramachi E., Noda N., Miyahara K., J. Nat. Prod., 73, 1846-1852 (2010).

4) Ono M., Kuwabata K., Kawasaki T., Miyahara K., Chem. Pharm. Bull., 40, 2674-2680 (1992).

5) Ono M., Yamada F., Noda N., Kawasaki T., Miyahara K., Chem. Pharm. Bull., 41, 1023-1026 (1993).

6) Ono M., Takagi-Taki Y., Honda-Yamada F., Noda N., Miyahara K., Chem. Pharm. Bull., 58, 666-672 (2010).

7) Ono M., Imao M., Miyahara K., Chem. Pharm. Bull., 58, 1232-1235 (2010).

8) Noda N., Tsuji K., Kawasaki T., Miyahara K., Hanazono H., Yang C.-R., Chem. Pharm. Bull., 43, 1061-1063 (1995).

9) Bah M., Pereda-Miranda R., Tetrahedron, 53, $9007-9022$ (1997).

10) Escalante-Sánchez E., Pereda-Miranda R., J. Nat. Prod., 70, 10291034 (2007).

11) Castañeda-Gómez J., Pereda-Miranda R., J. Nat. Prod., 74, 11481153 (2011).

12) Rosas-Ramírez D., Escalante-Sánchez E., Pereda-Miranda R., Phytochemistry, 72, 773-780 (2011).

13) Takigawa A., Muto H., Kabata K., Okawa M., Kinjo J., Yoshimitsu H., Nohara T., Ono M., J. Nat. Prod., 74, 2414-2419 (2011).

14) Demarco P. V., Farkas E., Doddrell D., Mylari B. L., Wenkert E., J. Am. Chem. Soc., 90, 5480-5486 (1968).

15) Pereda-Miranda R., Escalante-Sánchez E., Escobedo-Martínez C., J. Nat. Prod., 68, 226-230 (2005).

16) Escobedo-Martínez C., Pereda-Miranda R., J. Nat. Prod., 70, $974-$ 978 (2007). 